\title{
Acting, Movements, and the Three Important Components Configuration in Marginalizing Randai as an Entertainment Show
}

\author{
Indrayuda Indrayuda ${ }^{\bowtie}$ \\ Department of Drama, Dance, and Music, Faculty of Languages and Arts, \\ Universitas Negeri Padang, Indonesia
}

Received: March 18, 2019. Revised: May 18, 2019. Accepted: June 19, 2019

\begin{abstract}
The purpose of this research is to reveal how marginalized Randai as a performing art in the life of Minangkabau's people and their social culture in West Sumatra. This research is based on qualitative methodology with a descriptive method; this research is focused on the marginalization of Randai as the consequences of its lack of acting techniques, movement, and configuration. This research involved traditional artists, dance and Randai artists, indigenous elites, and the people managing the show. Data collection using live monitoring on the Randai performance and doing many interviews related to Randai as an art performance in Minangkabau's people's life. Besides that, the data also collected from documentary and literature studies. Data analysis was done using the ethnography method. The results showed that, in reality, the weakness of the Randai show is located on the acting, movement, and its configuration. The weakness of those three key elements is marginalizing the existence of Randai as an art show in social culture life. The lack of acting, movement, and configuration in the performance does not match the current demand of the people.
\end{abstract}

Keywords: Randai performance, acting, movement, configuration

How to Cite: Indrayuda. (2019). Acting, Movements, and the Three Important Components Configuration in Marginalizing Randai as an Entertainment Show. Harmonia: Journal of Arts Research And Education, 19(1), 98-110.

\section{INTRODUCTION}

The Minangkabau society has many pretty popular performance arts, one of which is called Randai. Randai is a local product that was made by the Minangkabau society in many nagari (villages). Every nagari has a certain characteristic in the aspect of the movement, costume, and music in its Randai arts. To this date, Randai performances can be seen in many events by the Minangkabau people in their naga$r i$; furthermore, Randai also got culturized and taught by the urban society and by many college students. Randai has become one of the national cultures even after its change during the colonial era. Today, Randai becomes a cultural heritage among the Minangkabau people and are still performed both in people's own nagaris, and overseas.

These days, the development of Randai performances faces obstacles; this can be seen from the decline in the number of spectators and the next generations of Randai. The researcher sees that in various villages in districts and cities in West Sumatra, Randai shows are often left behind by the audience, even though Randai is performed in front of its community; thus,

\footnotetext{
${ }^{\square}$ Corresponding author: Jl. Prof. Dr. Hamka, No.1 Air Tawar Barat Padang 25132, Indonesia

E-mail: indrayudayusuf@yahoo.co.id
} 
it can be said that the Randai show has lost its audience. Although the frequency of performances has not decreased significantly from the early 2000s, the audience has indirectly marginalized Randai from the entertainment arena in West Sumatra today. Researchers obtained information from several informants that the Randai show was considered to be less relevant to the rapid development of people's artistic tastes. Indirectly, technological growth has changed the mindset of the public artistic taste in Sumatra Barat. As time goes by, there has not been any significant changes in Randai performances, so that the public assumes that Randai is no longer part of their culture anymore.

\section{METHOD}

This study used a descriptive research method. The focus of the research, as well as the object of research, is the issue of the exclusion of Randai performances caused by the acting, movement, and configuration aspects. These are the most important aspects of the packaging of the show that need to be highlighted qualitatively. This research was conducted in several rural and urban areas in the province of West Sumatra. Researchers chose several key informants, namely, Randai tuo (elder), Randai actors, and Randai musicians. Other informants are managers of tourism and entertainment performance as well as the general public and customary elites and government elements. In addition, the researchers also selected informants from the owners of art galleries, performance art researchers, academics, and the Randai performing arts community.

The key instrument in this study is the researcher himself because the researcher acts as the designer and direct actor in collecting research data. The researcher also uses other devices such as audio and audiovisual recording devices; these tools function as an instrument in taking field data at the study site. In addition, in order for the data to remain original, faithful, and easy to store, researchers photographed and videotaped important moments from the Randai performances.

Data is collected through interviews, both structured and unstructured, which were guided by the interview guide sheet. Another data collection tool is direct observation, where the researcher observed the flow of each Randai show. In his observation, the researcher focused on two aspects, the form of packaging visually displayed on Randai, and the social settings as well as audience responses from the Randai show. All forms of observation must be guided by observation sheets. The researcher analyzed the data presented by Spradley, in ethnographic data analysis techniques which consist of: (1) determining research objects; (2) conducting field observations; (3) conducting domain analysis; (4) conducting focused observations; (5) conducting taxonomy analysis; (6) analyzing themes; and (7) writing a report.

The researcher conducted multiple data checks which were carried out repeatedly and carried out discussions with peers to ensure the validity of the data. Data triangulation was also carried out when collecting the data on the field so that the researcher obtains data certainty. In addition, the researcher examined the validity of the data with the help of several experts and mentors who were experts in the performing arts, which were conducted in the focus group discussion activities.

\section{RESULTS AND DISCUSSION}

\section{Randai Marginalization as a Performing Arts Entertainment}

The desires of people's tastes have an impact on the form changes and the packaging of performing arts, both modern and folk performing arts. Nowadays, the dynamics of people's tastes are moving forward rapidly; this is due to the ease with which the public accesses all information related to the form, pattern, and style of the performance art intended. Thus, the public wants a variety of new styles and variations of the art form. People always want things that are new, even if they re- 
quired to be commodified, elaborated, or recycled. This has an impact on the established art; established art does not want to adapt according to the wishes of the audience. In the end, arts like this will be marginalized in the market of entertainment performing arts.

Referring to the growth and development of information technology, all elements related to the performing arts were affected by the flow of change. Indirectly, established traditional arts need to be developed; things that are considered obsolete need to be adjusted and reconstructed, or modified or given a touch of color and other art styles. If this is not done, then the existence of the artwork will be easily eliminated from the arena of entertainment performing art competitions. The market will move from liking the arts to marginalizing them. One of the best ways is to bring about a change in the form of packaging for the art show, just like Randai art, where its existence has begun to be reduced by the weakness of its own artistic death. The issue of important elements in the Randai work is still structured like that too, and there is no change in the elements of acting, dialogue, configuration, and the legaran movement.

As stated by Jazuli (2001, p. 189), the occurrence of globalization, which has led to the presence of the entertainment and tourism industry, has an impact on the conceptual framework for the performing arts. This means that the presence of the entertainment and tourism industry has changed the face of performing arts products, which are oriented to the interests and desires of the market. Production house or art studio as a manufacturer of works of art will give birth to works of art that focus on working for the needs of tourist consumers and consumers of the entertainment industry. Thus, a transaction takes place between the artist as an art creator and the buyer as a connoisseur, which concerns the form of the packaging of the show. As a result, the show's packaging patterns appear in the form of solid, attractive, demonstrative, and are in a short du- ration. Performance art like this is a form of entertainment performance art concepts that must be addressed by creators from various studios and production houses.

Desfiarni (2013. P. 128) said that aesthetic elements such as movement, costumes, and other factors that build the value of an art performance, will affect the imagination of the audience. In turn, the performance will be determined by its aesthetic appeal, such as movement that is packaged in a form of work of art. Referring to the Randai show, it turns out that movement and acting, as well as its configuration, are important elements within a unified composition of the works of Randai art. The reality aspects of acting, movement, and configuration that exist in the Randai show has not been able to make Randai as a cultural focus, both for rural communities and urban communities in West Sumatra. The elements of movement, acting, and configuration should be of serious concern by current Randai artists in West Sumatra.

Randai, at this time, naturally and gradually began to recede from circulation. This incident means that the performance of Randai as an entertainment commodity is declining in value. The Randai audience community is increasingly diminishing in every Randai event. A Randai expert, Saparman, said that Randai was too rigid with its structure and packaging so that the movement and acting of the actors who acted as characters in the show had not been able to establish good interactions with the audience. The audience felt they had not found any communication and were not entertained from watching the Randai show.

Referring to Soedarsono's statement (1992, p. 12), good entertainment art is to have elements which include: (1) the artwork is a reflection of existing traditional art; (2) from the aspect of presenting the work, the performing arts must have a concise composition structure; (3) full of variety and enjoyable; (4) the work is easily digested by the audience and not too complicated. 
Referring to what was explained by Soedarsono and related to the current condition of the Randai performance, there has not been a meaningful relationship. The reality is that the Randai performance is still complicated; the narration is too long to be conveyed, which makes the audience bored. The tapping pattern of the galembong often repeated even though the story has changed from one scene to another. On the other hand, variations in terms of showing various combinations of movement techniques, the configuration has not completely changed. In the end, every Randai show performed by the Randai community has a small audience. When shown as entertainment for the general public, most of those who come to watch the show, are traditional artists and local elites. This means that the community has marginalized Randai art as a performing arts show in West Sumatra today.

Efrida (2016, p. 64) says that art in the Minangkabau community is something that is considered valuable if it has been given value by the community. This means that the community will provide value to the art if the art is in accordance with community needs. If the Minangkabau community considers the art to be irrelevant to the customs and habits of the community, then the art is considered to be of no value, so that the art will slowly be excluded from the community life. The value of art by the community can be caused by the form, use, and benefits of the art. Therefore, in the Randai show, there are several elements of the composition of Randai that are less relevant than the current public taste in art. In turn, the community considers the Randai performance to lose its artistic value. Therefore, the public has marginalized Randai performances unless there has been a fundamental change in the elements of the composition, such as in movement, costumes, music, or in the acting.

Randai, in its current form, has not changed since the era of independence, or even the Order Baru (New Order) era, where at that time, the Randai show was a communication media for government development messages, especially concerning the Keluarga Berencana (family planning) programs. But what has changed is only at the level of the story script, and not on the structure of the show, acting techniques, appearance techniques, or composition. Today, what is inherited by Randai artists from their teachers or previous heirs, remains that way and has never changed. Along with that, people's demands for Randai performances with innovative packaging are getting higher, so this has become a problem for Randai artists. As a result, the inability of these traditional artists to pack with new colors and styles at the Randai show has an impact on the marginalization of Randai as an entertainment performance art in West Sumatra.

Changes in the Randai show are only at the level of the story script, incorporating new song elements in the Randai accompaniment music, as well as the presence of a small portion of dance moves and a significant increase in the frequency of the galembong. But it is the tapping pattern of the galembong that often repeats and has been the same since the 1980s, causing the Randai show not to be dynamic, especially since it has lost its pencak silat bit. This pencak silat factor causes the Randai show to be less attractive to the community because the identity of the village where Randai grows and develops is seen from the movements of pencak silat, which are played by the Randai artists. Eventually, Randai lost its pencak silat identity, which resulted in the decline of local fanaticism towards the Randai performance. As a result, Randai shows have increasingly been marginalized by their own people.

\section{Randai Marginalization from the Acting Perspective}

According to the development of the form of performance from traditional entertainment art, there have been many shows that are packaged in an attractive and modern way, namely the presence of stage makeup. The acting done is proces- 
sed with gesture techniques and communicative expressions. The development was triggered by the emergence of information technology; it seems that the emergence of various YouTube videos that are easily accessed by people in various corners of the region. In turn, it has influenced the mindset of the audience of the traditional performing arts in West Sumatra.

The impact of some entertainment shows on YouTube has stimulated the imagination of the public towards a new spectacle. Thus, people will eventually compare what they have just watched on YouTube with what they have received as cultural heritage, which they have used as an entertainment art so far. In turn, they concluded that it turned out that the Randai entertainment show had lost its aesthetic appeal, this is due to the poor quality of the attractiveness of the actors in acting, their expressions are unable to reveal the role they are playing.

As Rizal Tanjung explained, according to the dramaturgy theory, Randai is currently losing actors who are able to act expressively and communicatively. Therefore, if the show is successful and responded well by the audience, then the artists must work on their acting techniques because so far, the Randai show only features actors with acting techniques who have not been able to explore their body when acting. The artists must work on their acting techniques because the Randai show is packed and focuses on the messages and literary art of speech delivered by the Randai performers.

Armeynd also criticized the issue of acting; according to his observations, Randai shows have not been able to provide something spectacular in terms of acting. The show director still struggles to direct the players in emulating the characters they play with expressive and communicative acting. The actors or the players often only talk without being able to act well, even when the actors are having a conversation with each other. Still, the acting does not appeal to the audience at all and often considered corny. Objectively, according to Armeynd, in fact, traditional Randai is in a literary value better than its acting technique. The speech literature can bring the audience's imagination more into the past. Through literary performances, the actors can manipulate the audience's feelings, as if they were brought to the past of Minangkabau.

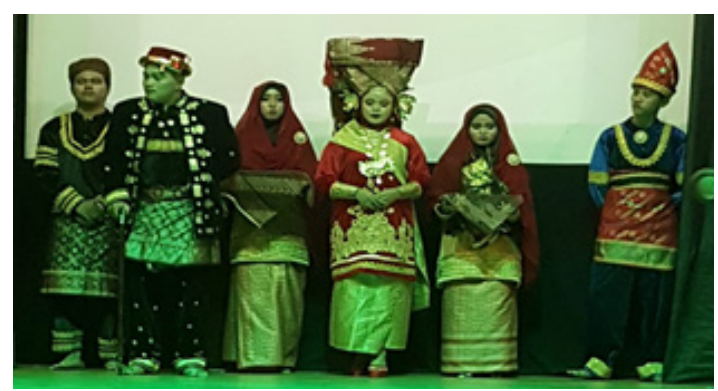

Figure 1. Acting techniques performed by the actors in the Randai performance

(Indrayuda's Documentation, 2019)

Ismar Maadis Datuak Putiah said Randai had lost its appeal in the aspect of acting or character. Especially at this time, Randai players in acting are less able to move to open space, so that the blocking they do feels stiff, and they often stay in one place without doing anything. The issue of acting is bothersome for the audience because the audience does not get any surprises from the expressions and acting styles of the actors. The Randai show is considered boring, so the audience feels "tortured" by their feelings and thoughts to understand the Randai show, which is considered too long as an entertainment show.

The researcher observed that in some traditional Randai performances so far, they were too focused on the delivery of the story by packaging the composition of the show so that it takes too long for the audience to watch this not so interesting entertainment. In fact, every actor performs with a rigid appearance; the transition between dialogue places from one room to another is less done. Actors are often too long in dialogue with other actors in one room, making the audience bored. The acting from the actors is not done with good gestures that are flexible either so 
that their expression can not reach the maximum potential from the aspect of acting. As a result, the audience has not been able to enjoy the acting of the actors fully.

Ade Suyandra said that many traditional directors in Randai shows have not been able to develop the talents of their actors in acting. Many Randai trainers let their actors improvise on the stage without focusing on their acting techniques. They are more focused on dialogue techniques using oral literature. The trainer's emphasis is only on speaking techniques using good oral literacy so that actors are able to dialogue by using classical Minangkabau literary techniques to the full. However, the dialogue without being accompanied by good acting techniques, then the performance Randai feels bland, thus making the audience less able to feel the interesting and unique actions by the actors.

According to Viveri Yudi, after Randai integrates with drama, which in turn uses story scripts and has actors who will portray the story, the acting of the performers inevitably must make the audience to fantasize so that the Randai performances really able to penetrate the minds and feelings of the audience. However, if the players' acting is sluggish and does not produce good gestures, the show will fail, and there will be a chance of Randai to be left behind by its own audience.

As Rizal Tanjung said, that Randai needed to transform into an innovative performing art, one of the things that needed to be changed was the acting technique since Randai has now been marketed to the tourism market and the entertainment industry both for local, national, regional and foreign tourists. Therefore, fundamental changes need to be made from the acting techniques of the actors, so that the theater performances can be enjoyed by the audience. But the reality is that the Randai show has begun to be abandoned by the audience; this is due to the weak acting techniques performed by the players.

Susmiarti (2015) said that the show that was often left by the audience was the phenomenon in the form of the packaging.
The packaging that includes elements such as composition, movement, expression, as well as acting, will be the focus of the attention of the audience. So if the acting element is problematic, then the show will disturb the imagination of the audience, and the audience will move from their seats. Therefore, the focus of the audience is on the innovative change of a show, meaning that an entertainment show must make an update of its component elements. If there is no renewal, then the performance will be abandoned by the audience.

Along with that, Rusliana (2011, p. 99) said that the marginalization of traditional performing arts in the competitive entertainment performance art market is caused by inaccurate forms, motion design, music, costume design, and dynamics, working patterns, and the performance techniques that never change. In addition, the packaging of the presentation is not neatly patterned, and the elements of the composition have not been explored properly. Because composition elements such as the actors' acting need to be worked on seriously, the actors need to be able to play roles with good quality and are able to express themselves that can make the audience hypnotized.

According to Rangga \& Abdillah (2019, p. 7), a search or exploration process to find a form of characterization that wants to be played by each actor needs to be done step-by-step and requires appropriate techniques. Some techniques are very necessary so that actors understand well how to approach the character being played. This is inversely proportional to the Randai show, where the Randai show does not yet have an actor who plays the character with the right technique, so the show is not communicative.

In reality, so far, Randai shows are often lacking in acting techniques, so the performances are less attractive from the entertainment aspect. Thus, the weakness of the acting technique helps to marginalize the existence of Randai as a spectacle of public entertainment in various nagari (villages) today in West Sumatra. Actors' 
weaknesses in acting have been detrimental to the quality of Randai performances as an art of folk entertainment. The issue of actors who have not been able to act properly has an impact on the lack of expressiveness of Randai shows, and this has encouraged the audience to marginalize Randai performances in various places.

Referring to the fact that Randai art has entertainment value for the Minangkabau people, Randai cultivation as an entertainment media must be able to provide something of entertainment value to the community, both through movement, music, and the acting of the players. If one element is not able to be presented properly, the Minangkabau people, as a critical community, will leave and marginalize the show even if Randai is a cultural heritage of the Minangkabau people. This means that the aesthetic tastes of the performing arts of the Minangkabau community lie in the imagination and personal interpretation related to the objects they see (Hidayat, Indrayuda, I., \& Syahrel, 2013).

Minangkabau society is very dynamic and very responsive to various changes. As Kuswarsantyo (2008: 41) says that the growth of art is like a chain; if one breaks, it will break the other. Therefore, changes in the performing arts will be interrelated; the relationship between the art form and the tastes of the audience becomes an inseparable link. Therefore, if there has not been a change in active techniques to more innovative techniques, then Randai performances should not be expected to become the focus of entertainment for people in various villages and cities in West Sumatra.

Referring to Kuswarsantyo's statement above, changes in people's tastes towards the performing arts essentially and substantially have an impact on people's desire for improvement of the acting techniques in Randai performances. Thus, there is a positive response from the community's criticism of changes in the Randai show model; this response needs to be addressed wisely by the Randai artists.
In turn, Randai performances will not turn into a low-audience-count show. Therefore, one of the ways that they do is change the old acting techniques by bringing up innovative acting techniques. With hope, if this change can be made, then the Randai show will not become a marginal art anymore.

The pros and cons of the Randai show depended on how the Randai players presented the text stories in the sense of having a dialogue and acting and moving on stage or arena (Sakti, 2010, p. 166). Referring to what was explained by Sakti, this time, the public sees the Randai show not being able to be delivered by the players well, especially from the acting, aspects of literature, and movement. As a result of the poor performance of the show, the community has slowly marginalized the existence of Randai as an entertainment performance art in West Sumatra.

Randai Marginalization from the Movement Perspective

Based on the study that the researcher had done, the artistic and aesthetic power of the Randai show currently lies only in the literary elements and the $g a$ lembong pattern, while the dominance of the galembong pattern has degraded the pencak silat movement. As a regional art that originally began with the motion of pencak silat, the silat aspect is no longer visible from the Randai show. Initially, the composition of the movements in the Randai show are movements originating from pencak silat, which is one of the identities from which the Randai art originated. This means that by only looking at the variance of movement and techniques played by the actors of Randai (Randai players), the audience can already guess that the Randai art originates from a particular nagari (village). By focusing on the galembong pattern on the Randai packaging at this time, the impact on the agility and dynamics of the Randai show began to diminish, although its uniqueness is still apparent. 


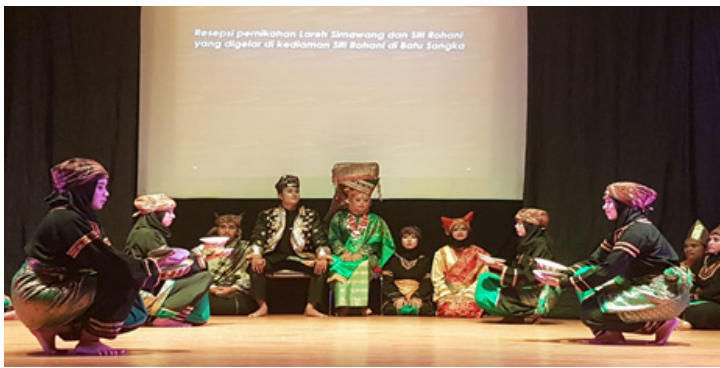

Figure 2. The dance movement within the Randai show. (Indrayuda's Documentation, 2019)

Today's society feels their regional identity has begun to disappear along with the dominance of the galembong pat movement in Randai performances because the galembong pat is not based on silat (silek in the Minangkabau language). The $g a-$ lembong pat is merely a displacement of percussion rhythm in music, meaning that it is not a part of the movement but rather a musical sound motif in the form of rhythm that is transferred to the Randai players' pants. The technique of the beating of these pants is done by hand and body movements. Still, it is not really the main part of the main movement that is in Randai. The Randai art originally grew and developed in traditional silat pencak silat colleges in Minangkabau; because of that, all the main elements of movement in Randai shows are based on the movements of pencak silat with their variations being the galembong pat as the palam (cue). That is why we could call the Randai players as warriors.

Changes that occur in today's Randai performance are mainly in the aspects of movement, namely the loss of diversity of dynamic and varied movements of silat. Today in the Randai show, what is present is the dominance of the galembong patting motion, which is actually just a sound transfer with additional movement - a rhythm that is transferred from gendang to the clapping and patting of the galembong. This is often done in repetitive amounts with exactly the same motives, which makes the audience bored. In turn, the galembong pat and the sound motif never change during the performance even though the flow has changed. In essence, the mo- tion in the Randai show is a manifestation of the content of the story that will be told through dialogue by several actors.

According to Armeynd, the reality is that Randai is simpler in its packaging. In the aspect of the movement, there is often a repetition of motives from one technique of galembong pat to another, and in each transition scene, always uses the same motif. The movement on the legaran (circle configuration) does not change very much from one formation to another. The varying power of pencak silat movements is no longer visible, due to the dominance of the more prominent galembong tap and applause. In turn, the audience will witness a stagnant show, and this will have an impact on the dynamics of the Randai show, which will become monotonous from the aspect of the movement.

Putra (2012, p.169) said that the development of the tourism industry in Indonesia had stimulated the emergence of new creativity and new ideas in the form of performance art packaging. Therefore, the performance of performing arts in the context of packaging will be a loss for the performance art itself because the performance art is not considered dynamic and attractive and revolves around the same form, so the performance becomes monotonous and is seen as arid from variation. Meanwhile, Indrayuda (2016), responding to the growth of the performing arts entertainment in the era of tourism, said that artists are required to continue to develop in accordance with the growth of people's tastes. This means that local artists need not be too idealistic about their work. Thus artists are required to be more creative to renew their art from the packaging aspects of the show; therefore, the use of idealism that is still surviving must be adapted to new developments in the aspect of the movement.

Maadis (2012, p. 85) said that these days, the Randai show is still considered unique to foreign tourists because of the $g a$ lembong pat, but for Minangkabau artists and academic artists in general in West Sumatra, the movement feels monotonous 
and lacks variety, similar to the views of the supporters themselves in various villages in West Sumatra because their identity as the owner of the Randai art no longer appears in the movement that exists at the intended Randai show.

Based on Maadis' explanation above, it is relevant to the fact that researchers find today, namely that many supporters of Randai arts are less appreciative of the current Randai performances. Local people who feel that they own the Randai art want a change from the element of movement in the Randai show, i.e., collaborating the technique of pencak silat movement with various forms with the rhythm of the galembong pat while still giving a large portion to the pencak silat aspect.

In the initial tradition, Randai is based on the local culture of the owner's community; it means that if the culture is no longer carried out, then the culture will be marginalized by the community. So that the existence of Randai if it is no longer responded to by the community, it means that in the Randai show, the people no longer see it as the present heritage of the community's traditions, which they still acknowledge. As a cultural system, tradition gives meaning to the behavior of the supporting community, both in social life and in the arts (Hum, and Kuniang, 2015, p. 109). Today, people look down on Randai and no longer liken it to new cloth, but instead a worn fabric; then Randai will be marginalized slowly by the community owner.

Wendy (2014, p. 36) explains that silek or silat is the identity of a nagari (village) in Minangkabau because, in the past, the community was taught in surau (traditional mosque) about the problem of martial arts, dendang music, and kaba or stories. These three aspects are already present in Randai art. Therefore, the existence of Randai cannot be separated from pencak silat, namely pencak silat whose flow refers to the origin of the Randai ownership area.

It was concluded that the current marginalization of Randai in the commu- nity is due to the reduction in the various forms of pencak silat movements in the Randai show. Although the gesture of hand-clapping and the galembong patting is a unique attraction, because it is done with less variety and is always repetitive, makes the audience dislike it. The audience wanted to bring back the collaboration between pencak silat movements with the tapping and the galembong to become an aesthetic and artistic unity in the form of new motifs from the packaging of the Randai show.

\section{Randai Marginalization from the Config- uration Perspective}

According to Wendy (2014, p. 39), traditionally, the configuration pattern of Randai art is a circle by placing an actor in the middle of the arena of other Randai actors. Similarly, Maadis (2012, p. 53) and Harun (1980, p. 79) also said that the formation or configuration of the Randai show is a circle called "legaran." All activities such as performing silat, hand-clapping, and galembong tapping and when the actors are having a dialogue is all done inside the legaran.

Observing the development of contemporary tastes of art both at the local and regional and global levels, art lovers or connoisseurs of art have never liked the establishment of art. Therefore, established arts will become cultural monuments and not become an entertainment consumption for the audience. Thus, the Randai show is classified by the public today as an established art with its configuration form.

Based on the study conducted by the researcher in various villages and cities, many viewers give their criticism of the very monotonous configuration elements of the Randai show because Randai only shows one circle configuration without having any variation that can satisfy the audience when in fact there is an opportunity to provide the audience with a new experiment by increasing the configuration of the circle. This has received a lot of criticism from the audience.

Along with that, Cauto, Nasbahri, 
and Indrayuda (2013, p. 81) said that art is bound to space and time; old art will die and be replaced by new art that is more relevant to the tastes of the people who use the art. Old art will be able to survive if old art is given new makeup, so old art is relevant again to the reality of human development that uses it. Thus art is not absolute; art is not permanent in the eyes of society, and art is an imitation that is continuously flowing so that art can be said to live in harmony with the lives of people who created and used it.

Based on the evolution of Randai in the 1920s with the appearance of the king's school in Bukittinggi, it introduced elements of drama or story in the Randai show (Indrayuda, 2013). Pramayoza (2012) also stated about the rampant performances of Tonil Melayu in several areas in Minangkabau since 1888. In addition, Wendy (2014, p. 40) tells of the presence of Malayspeaking tonil (theatrical play) with the Minangkabau dialect and the presence of a king's school, which has triggered the production of drama performances with stories. The kaba (story) has given rise to a new evolution in the Randai performance from only a circular movement play by the silat fighters who collaborated with dramas or stories that use plays or actors in their performances. Finally, in 1927, a collection of Randai groups from Payakumbuh emerged and played a form of Randai that had evolved earlier with the Simarantang story script.

The Randai show has evolved since the 1920s in West Sumatra. Referring to the problem of transformation and evolution, right now, the people's desire to change the order of Randai format as performance art is felt to be no harm. Therefore, the researcher sees the reality now that the community is saturated with the formations or configurations that never change, meaning the audience wants a change in the configuration aspect.

The reality today is that many people complain about the configuration presented in the Randai show, the public believes that the show has never changed from one form of legaran. According to the community, if there is an agreement from the community on the changes that should be made, then changes should be made, especially from the aspect of the show. Today many Randai shows are marginalized by the community people themselves, and they turn to more dynamic shows and innovations such as creative dance or the $t a$ lempong goyang musical performances (mixed music).

Sugihartono and Falasifah (2016, p. 61) said that in today's performance show, the most important thing is to do a representation of the cultural forms that are rooted in society. The representation is packaged in a new form so that it is more attractive to the audience. This has been done by traditional artists in Jakarta in the case of the Lenong show. Therefore, the show that is watched by viewers is a show that has been packaged in a new form, so that the show can be of interest to many viewers. The conclusion from the above explanation is that every traditional art performance must be transformed into a new form, which can adjust to the desires of the people's tastes.

Referring to Sugihartono's explanation, it should be done by artists and managers of Randai in various studios or various regions in West Sumatra, so that Randai performances can be enjoyed and continue to be sought after by the local community. It turned out that the Randai performance, which had been considered a mainstream art, was seen by the public as an established performance art and did not want to leave its establishment state. In the end, the configuration form shown has never changed, so that the Randai performance is currently lacking in demand by the local community. Current Randai representation is still about cultural representations of the past, whereas today, the public wants the representations embodied by the Randai performances to represent the present time. 


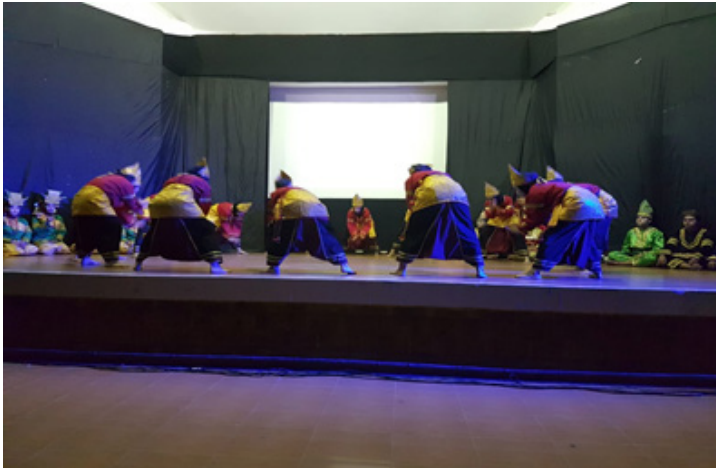

Figure 3. The legaran configuration in the Randai performance.

(Indrayuda's Documentation, 2019)

Artworks are human endeavors to bring the dream world imagined; when fantasizing, an artist is limited by the reality of the world that already exists. Besides, art emerges from a rebellion of souls. In addition to the artist, the audience is also a wanderer in the living space (Belvage, 2015 , p. 167). Therefore, art needs to make leaps that preceded its era. One of the efforts in making those leaps was to make various innovations and modifications to the composition elements of the performance artwork. If they do not make a breakthrough for change, the performance art will become a monument that is only seen as part of past history by the audience.

Therefore, it can be concluded that the Randai show from the aspect of its composition currently has stagnated, eventually impacting the marginalization by the supporting community. One of the aspects of the composition element is the configuration problem. The configuration present in the Randai show is very minimalist, meaning that the configuration only consists of one form of legaran. Currently, At present, the performing arts are getting richer with variations from various forms of composition elements, the Randai show, on the other hand, feels less appealing by the audience by only bringing up one configuration form. Thus, the Randai show is increasingly losing viewers, despite efforts to bring the Randai performance art to schools in West Sumatra.

\section{CONCLUSION}

After observing Randai performances, the reality is that Randai is still convoluted, taking too long for the narration to be delivered, which makes the audience bored. At the same time, variations in the aspects of movement, music, acting, and configuration techniques are still not found. Randai performances also have repeating galembong patting patterns even after the story has changed from one scene to another. In the end, every Randai show that is performed by the Randai community has a low amount of audience from the public or other art connoisseurs. Besides that, important composition elements such as pencak silat movements, actors' performances, and configuration have not been able to be presented to the audience as something of value. In turn, randai performances are increasingly marginalized by the audience.

The exclusion of Randai at this time in the community is mainly caused by the reduction of various forms of the movements of pencak silat in the Randai show. Although the gesture and the tapping in galembong pat is a unique attraction, because it is done with less variety and is always repetitive, and almost exist in every Randai performance, it makes the audience dislike it. The audience wanted to bring back the fusion between pencak silat movements, hand-clapping, and the galembong pat to become an aesthetic and artistic unity in the form of new motifs in the Randai show.

It turns out that the Randai performance, which had been considered a mainstream art, is seen by the public as an already established performance art and does not seem to want to leave its established state. In the end, the configuration form displayed has never changed, so that the Randai performance is currently lacking in demand by the local community. Randai images are still about cultural representations of the past. In contrast, today, the public wants representation represented by randai performances as repre- 
sentations of the present, one of which is through new and artistic and innovative configurations.

\section{REFERENCES}

Belvage, R. H. (2015). Pada Suatu Drama: Studi Seni Pagelaran dalam Wacana Pergerakan. Jurnal Kajian Seni, 1(2), 166-178.

Cauto, Nasbahri \& Indrayuda. (2013). Pengantar Sosisologi Seni. Padang: UNP Press.

Desfiarni. (2013). Tinjauan Estetika Tari Piriang Jorong Limau Sundai Pasir Talang Solok Selatan. Jurnal Humanus, 12 (2).

Efrida. (2016). Estetika Minangkabau dalam Gerak Tari Bujang Sembilan. Jurnal Ekspresi Seni, 18 (1).

Harun, Khairul. (1980). Kesenian Randai di Minangkabau. Padang: Proyek Bidang Kesenian Kanwil Pendidikan dan Kebudayaan Sumbar.

Hidayat, R., Indrayuda, I., \& Syahrel, S. (2013). Upaya Penggalakan Randai dan Nagari Ampu. Jurnal Sendratasik, 2(1), 75-85.

Hum, A. M., \& Kuniang, E. K. N. (2015). Nilai-nilai Pendidikan Karakter dalam Randai Bujang Sampai. Jurnal Peradaban Melayu, 10, 108-122.

Indrayuda, (2013).Tari Sebagai Budaya dan Pengetahuan. Padang: UNP Press.

Indrayuda, I. (2015). Continuity of Tradition Dance: Acedemicians' Intervention on Artists and Performing Arts Groups. Harmonia Journal of Arts Research and Education, 15(2).

Indrayuda, I. (2016). The Existence of Local Wisdom Value Through Minangkabau Dance Creation Representation in Present Time. Harmonia: Journal of Arts Research and Education, 16(2), 143-152.

Indrayuda, I. (2017). The Domination of Female in Galombang Dance: Between Traditional Idealism and Use to Performing Arts Market. Harmonia: Journal Of Arts Research And Edu- cation, 17 (2).

Jamal, Emral. (2015). "Randai Suatu Warisan Budaya Masyarakat Minangkabau dan Eksistensi Sastra Lisan", Ceramah Budaya di Salimbado Kultural, tanggal 23 Maret 2015.

Jazuli, M. (2001). Paradigma Seni Pertunjukan. Yogyakarta: Lentera.

Kuntowijoyo. (2006). Budaya dan Masyarakat (Edisi Paripurna). Yogyakarta: Tiara Wacana.

Kuswarsantyo. (2008). “Pengaruh Sosiokultural Tayub terhadap Perilaku Masyarakat Desa Karangsari, Semin Gunung Kidul. Hasil Penelitian tidak diterbitkan. Yogyakarta; Sendratasik FBS UNY.

Maadis, I. (2012). Reposisi Kesenian Randai Sebagai Seni Pertunjukan Rakyat Minangkabau dalam Kehidupan Berbudaya Masa Kini. Padang: LKAAM Sumbar.

Pramayoza, D. (2012). Sandiwara Kampuang di Sumatera Barat: Suatu Tinjauan Dramaturgi Atas Drama Poskolonial, Tesis pada Program Studi Pengkajian Seni Pertunjukan dan Seni Rupa, Sekolah Pascasarjana, Universitas Gadjah Mada, Yogyakarta.

Putra, B. H. (2012). Pengembangan Model Konservasi Kesenian Lokal sebagai Kemasan Seni Wisata di Kabupaten Semarang. Harmonia: Journal Of Arts Research And Education, 12(2).

Rangga Diputra, R. I. Z. Q. I., \& Abdillah, A. (2019). Teknik Keaktoran Tokoh Jordana Pada Naskah “Orang Kaya Baru" Karya Moliere Saduran Nano Riantiarno Sutradara. Solah, 8(1).

Rusliana, Iyus. (2011). "Kreativitas dalam Penyajian Tari Tradisi Sunda". Jurnal Panggung Vol.21 Nomor.4 Oktober 2011.

Sakti, S. D. E. (2010). Teks Randai Umbuik Mudo Karya Musra Dahrizal. Wana Etnik, 1(2), 165-178.

Soedarsono, R. (1992). "Bentuk Penyajian Seni Pertunjukan dan Pariwisata di Indonesia", Ceramah Forum Ilmiah Gelar Budaya Nusantara di Taman Mini Indonesia Indah, tanggal 13-16 
Juli 1992.

Sugihartono, R. A., \& Falasifah, A. (2016).

Representasi Kesenian Tradisi Lenong Betawi Pada Tayangan Drama Komedi Nglenong Nyok Di Trans TV. Capture: Jurnal Seni Media Rekam, $5(2)$.
Susmiarti, S. (2015). Tari Kain dalam Ranah Industri Hiburan: sebuah Problematika Kemasan dan Pelestarian. Humanus, 14(2), 158-164.

Wendy, H. S. (2014). Dramaturgi Teater Rakyat Randai di Minangkabau. Jurnal Kajian Seni, 1(1), 32-47. 